\title{
Corporate Governance and Financial Reporting Quality in Selected Nigerian Company
}

\author{
Onuorah, Anastasia Chi-Chi (PhD), Imene Oghenefegha Friday \\ Department of Accounting, Banking and Finance, Delta State University, Asaba, Delta State Nigeria \\ Correspondent Author's e-mail: anastasiaonuorah@yahoo.com
}

\begin{abstract}
This paper evaluated the level of performance of some selected companies ranging from commodities, brewery, banking, oil and gas and beverages in terms of corporate governance measure indictors on the firm quality of financial reporting in Nigeria. The data were collected from 2006 to 2015. Econometric analysis were conducted and the result suggests that the correlation among corporate governance indicators of board structure (size-BRDSZ and independence-BRDID), audit quality (audit committee size (ADCMZ), the quality of external audit (EADTQ) as measured by the presence of an auditor among the big-4), board experience (i.e. experience-BRDEX) and financial reporting quality is $93.47 \%$. The independent variables can explain the variation in the FRQDA by $54.29 \%$. There is overall significance among the parameters measuring financial reporting quality as discretionary accruals of firm (FRQDA). Board structure (size-BRDSZ), board experience (experience-BRDEX) and the quality of external audit (EADTQ) have positive impact on the financial reporting quality measured by the discretionary accruals of firm (FRQDA) by 16.01, 0.05 and 2.75. However, independent directors on the board of firm (independence-BRDID) and audit quality (audit committee size (ADCMZ) negatively affect financial reporting quality measured by the discretionary accruals of firm (FRQDA) as much as 0.99 and 20.01. Guarantee Trust Bank Plc. among the five selected companies of study in Nigeria has better performance of financial reporting based on board structure (size-BRDSZ) and audit committee size (ADCMZ). This revealed that there is short run relationship among Audit quality (audit committee size (ADCMZ), and the quality of external audit (EADTQ) as measured by the presence of an auditor among the big-4) and board experience (i.e. experience-BRDEX) have not granger cause FRQDA. It further recommended that greater focus on corporate governance indicators so as to bring about global standard financial reporting in the Nigerian emerging market for investment opportunity.
\end{abstract}

Keywords: Corporate, reporting, board size and structure, committee, companies, quality.

\section{Introduction}

In the words of (Arabsalehi and Ziaee, 2010) Corporate Governance Code of Nigeria, 2003) were considered as benchmark in corporate entity. They help companies to reduce mismanagement, remedy any deficiencies in governance mechanisms, to prevent abuse of power and to manage risks effectively (Jouini, 2013). Although it is believed that compliance with these recommendations is the essential basis for evaluating the quality of the governance system, and therefore the protection of the reputation of the company and the interest of the shareholders. However, on the path of the shareholders, quality and reliable information (especially on the operations of the directors) has become a commodity that must be paid for in order to effectively and efficiently assess their performance. Hence, the shareholders' direct and indirect investment in corporate governance mechanisms (agency cost) is aimed at increasing their confidence in the quality of financial information presented by the directors.

The bounded rationality of the shareholders (i.e. Principal) presents a platform for the opportunistic tendencies of directors (i.e. agent). This reveals a gap between the information-need of shareholders and the level of confidence they have in the quality financial reports presented by directors because it is through the same financial reports that the shareholders and other external stakeholders can assess the performance of the directors. The agency theory has also 
revealed that "When the principal has enough information to assess the activities and performance of the agent, such agent will tend to act in the best interest of the principal". As a result of this and with the prior cases of financial scandal, both local and international communities have raised many criticisms about the quality of financial reports (Orlando, 2010). The purpose of this study is to investigate the impact of corporate governance and financial reporting quality performance in selected Nigeria Company. The specific objectives are: to examine the effect of directors on the board of firm, independent directors on the board of firm, size of the audit committee in firm, presence of an internal audit committee and the use of an external auditor among the big-4 and presence of qualified and well experienced directors on the board of firm on financial reporting quality measured by the discretionary accruals of firm.

\section{Literature review}

\subsection{Corporate Governance}

Although corporate governance have been exhaustively defined by Zain-aldini Maymand (2011) as a mechanism for managing, directing and supervising the activities of the company with the aim of creating value for shareholders. However, for the purpose of this study, we would consider a definition that embraces a wider view (i.e. including the shareholders' perspective) of corporate governance. Hence, corporate governance is defined as the set of structures, processes, customs, policies, laws, and procedures that define the way owners' resources are administered or controlled in a corporation, in order to protect the interests of the owners. These structures customs, policies, laws and procedures determine the way a corporation is being governed. These structures guide the self-seeking and opportunistic tendencies of directors and also protect the owners' interest (Mehrani and Safarzade, 2011), and hence, require certain costs (agency costs) to maintain them.

Shareholders invest in the corporate governance system as a way of getting the directors to pursue their interest (maximizing returns) in a fair manner. Such investments are evident in the structure of the board (i.e. its size and independence), versatility of the board (i.e. directors' qualification and experience) and audit quality. Shareholders invest in these key areas of the corporation in order to add value to the corporate governance system which is expected to improve performance and also improve the quality of financial reports as proposed by the regulators (Mehrani and Safarzade, 2011). However, when the quality of information in the financial report is high, then shareholders' confidence on these reports is also assumes to be high and vise-versa.

This study intends to determine how the corporate governance system affects the financial reporting quality, which will ultimately determine the level of shareholders' confidence. For this study, three areas of corporate governance are extensively considered, and these include; the structure of the board (with emphases on size and independence), versatility of the board (with emphases on directors' qualification and experience) and the quality of audit (with emphases on the presence of an internal audit committee and the use of an external auditor among the big-4).

\subsection{Financial Reporting Quality}

Although to assess the quality of financial reporting, several measures have suggested in prior studies (VanBeest, Braam and Boelens, 2009). These included the accrual models, the model of earnings relevance, and other methods incorporating qualitative characteristics (Jouini, 2013). However, major strand of financial reporting quality in prior studies is the use of earnings management which examines managers' use of discretionary accruals to shift reported income among fiscal periods. The discretionary accruals are determined by separating the non-discretionary accruals from the total accruals. According to Dechow, Ge and Schrand (2010), "non-discretionary accruals can detect adjustments that reflect fundamental performance and the discretionary accruals capture distortions caused by application of earnings management or the accounting standards". Hence in this study, we would adopt the modified Jones model of the accrual method as proposed in (Dechow, Sloan, and Sweeney 1995 and Dechow and Dichev, 2002).

\subsection{Board Structure and Financial Reporting Quality}

In board structure, we would examine the size of the board (i.e. the number of directors on the board) and the independence of the board (i.e. the percentage of independent directors on the board). Prior studies have revealed contradictory results on the relationships between board size, board independence and financial reporting quality.

On board size, Jensen (1993) among other early studies revealed that a small number of directors will foster a high degree of coordination and communication between them and managers, which is expected to increase the quality of 
financial reports. Godard (2001) and Bradbury, Mark and Tan (2006) argued through their findings that a large board size may awaken elements of managerial entrenchment. It also increases coordination and communication problem, hence, declining directors' ability to oversee management. The studies of Vafeas (2005) and Ahmed, Hossain and Adams (2006) also found that a large board size tends to reduce the information content of income and also increases earnings management. However, Byard, Li and Weintrop (2006) argued that a high number directors on the board helps to ensure the value relevance of financial statements.

On board independence, Peasnell, Pope and Young (2000) and Klein (2002) revealed through their findings that an independent board mitigates earnings management. Bushman, Chen, Engel and Smith (2004), Vafeas (2005) and Karamanou and Vafeas (2005) concluded that information quality increases with the increase in percentage of outside or independent directors. In other contexts, Firth, Fung and Rui (2007) indicated that the presence of independent directors improves he earnings quality of Chinese firms. Dimitropoulos and Asteriou (2010) also confirmed this finding using a sample of Greek firms. While Nesrine and Abdelwahid (2011) concludes that although board independence improves earning quality, but in the case of Tunisian firms, this may not be possible given the limited number of independent directors and the high frequency of CEO duality. However, the studies of Petra (2007), Bradbury, Mak and Tan (2006) and Ahmed, Hossain and Adams (2006) suggested based on their findings, that the independent directors are not competent enough to control the managers, and that their presence on the board has no effort in ensuring financial reporting quality. The study of Cornett, Mc Nutt and Tehranian (2009) revealed that board independence negatively related to financial reporting quality.

\subsection{Audit Quality and Financial Reporting Quality}

In audit quality, we look at the presence of an effective internal audit committee and the use of an external auditor that is among the big-4 (i.e. Deloitte Touche Tohmatsu, PricewaterhouseCoopers, Ernst \& Young and KPMG).

The audit committee is structured to ensure reliable and high quality financial report as it oversees the financial reporting process as well as auditing the financial statements. Rezaee (2008), and Rezaee and Riley (2010) states that the roles and functions of the internal audit committee are crucial in the practical aspect of corporate governance, especially their drive towards ensuring quality in financial reporting as revealed in their result. While the findings of Farber (2005), Kent and Stewart (2008) and Erena and Tehulu (2012) reveals that the presence of audit committee and their frequent meetings can reduce the incidence of financial reporting problems. The result of Parwit, Smith and Wood (2009) and Greco (2012) revealed that companies with good internal audit quality function will not encourage earnings manipulations; as such companies will have decreased accrual values.

The use of an external auditor among the big-4 given above is a move my company owners (shareholders) to ensure that financial statements shows a true and fair view of the financial statements, hence, boosting their confidence of these financial statements. Leung, Morris and Gray (2005) revealed through their findings that the presence of an external auditor among the big-4 signals quality in the financial information disclosed by directors, and the integrity of financial information.

\subsection{Board Experience and Financial Reporting Quality}

The uniqueness of this study is the introduction of extra corporate governance measure "board versatility". Shareholders in their bid to increase their confidence in the financial reports ensure that only qualified and well experienced directors are on the board. In board versatility, we would examine the qualification and experience of the director on the board in relation to ensuring financial reporting quality.

\section{Research Method}

For the purpose of this study, the descriptive research design is used and the study period is ten (10) years, spread from 2006 to 2015. The study population is all the company on Nigeria Stock Exchange listings within the study periods. A sample of 5 companies spread across three main sectors of the economy (i.e. manufacturing, service and banking) was selected based on the research purposive sampling procedure for the study. The variables were subjected to econometric tests which suggested VAR model as appropriate for the analysis. 


\subsection{Model Specification}

The many previous studies have Jones Model. Jones (1991) proposed a model that attempts to control for the effects of changes in a firm's economic circumstances on nondiscretionary accruals and popularly called Jones Model for nondiscretionary accruals in the event year. However, this study model is based on the specified equation below:

$\mathrm{FRQ}_{\text {DA-it }}=\alpha_{0}+\alpha_{1}$ BRDSZ $_{\mathrm{it}}+\alpha_{2} \mathrm{BRDID}_{\mathrm{it}}+\alpha_{3} \mathrm{BRDEX}_{\mathrm{it}}+\alpha_{4} \mathrm{ADCMZ}_{\mathrm{it}}+\alpha_{5} \mathrm{EADTQ}_{\mathrm{it}}+\varepsilon_{\mathrm{t}}$

Where:

FRQDA-it is financial reporting quality measured by the discretionary accruals of firm $\mathrm{i}$ in year $\mathrm{t}$.

BRDSZ $_{\mathrm{it}}$ is the number of directors on the board of firm $\mathrm{i}$ in year $\mathrm{t}$.

BRDID $_{\mathrm{it}}$ is the percentage of independent directors on the board of firm $\mathrm{i}$ in year $\mathrm{t}$.

$\mathrm{ADCMZ}_{\mathrm{it}} \quad$ is the size of the audit committee in firm $\mathrm{i}$ and in year $\mathrm{t}$.

EADTQ $_{\text {it }} \quad$ is presence of an internal audit committee and the use of an external auditor among the big- 4 .

BRDEX $_{\text {it }} \quad$ is the presence of qualified and well experienced directors on the board of firm $\mathrm{i}$ in year $\mathrm{t}$.

The dependent variables are corporate governance indicators of board structure (size-BRDSZ and independenceBRDID), audit quality (audit committee size (ADCMZ), and the quality of external audit (EADTQ) as measured by the presence of an auditor among the big-4), and board experience (i.e. experience-BRDEX) which have all been well defined and explained in the previous sections of this paper. The dependent variable of this study "financial reporting quality" is approximated by the discretionary accruals as used by several authors.

\section{Empirical Analysis and Discussion of Result}

The dependent variables are corporate governance indicators of board structure (size-BRDSZ and independenceBRDID), audit quality (audit committee size (ADCMZ), and the quality of external audit (EADTQ) as measured by the presence of an auditor among the big-4), and board experience (i.e. experience-BRDEX) which have all been well defined and explained in the model specification. The dependent variable of this study "financial reporting quality" is approximated by the discretionary accruals as used by several authors. The diagnostic check help to give the model estimate direction.

Table 1: Diagnostic Check for Residual

\begin{tabular}{|l|c|c|c|l|}
\hline Residuals & Test & Value & Pvalue & Conclusion \\
\hline Normality & JB-test & 0.6200 & 0.7334 & Not Normal \\
\hline Serial & LM-test & 1.5084 & 0.3986 & Not Serially Correlated \\
\hline Heteroskedastic & ARCH & 0.3236 & 0.5871 & Presence of homoskedasticity \\
\hline Stability & Ramsey Ret & 8.6587 & 0.0099 & Stable \\
\hline
\end{tabular}

Source: E-views result extract, 2016.

Diagnostic test of the corporate governance model variables is not normally distributed. The series are not serially correlation but it is stable with presence of homoscedasticity. Diagnostic check reveals that all the assumptions of the OLS is not satisfied because test of serial correlation is violated, hence, the appropriate model estimate for this study is VAR model based on the unit root test. Unit root test fail because of the violation of normality caused by the small size use in the study. 
Table 2: Relative and Global Statistics Results

Date: 02/18/16 Time: 21:58

Sample(adjusted): 20082015

Included observations: 8 after adjusting endpoints

Standard errors \& t-statistics in parentheses

\begin{tabular}{cc}
\hline \hline & FRQDA \\
\hline \hline FRQDA(-1) & 0.557945 \\
& $(0.66194)$ \\
& $(0.84289)$ \\
& 0.352241 \\
FRQDA(-2) & $(0.69597)$ \\
& $(0.50612)$ \\
& 16.01850 \\
BRDSZ & $(24.5208)$ \\
& $(0.65326)$ \\
& -0.993787 \\
BRDID & $(0.53919)$ \\
& $(-1.84313)$ \\
& \\
BRDEX & 0.055311 \\
& $(0.44105)$ \\
& $(0.12541)$
\end{tabular}

\begin{tabular}{lr}
\multicolumn{1}{c}{ ADCMZ } & -20.01456 \\
& $(28.8052)$ \\
& $(-0.69483)$ \\
\multicolumn{1}{c}{ EADTQ } & 2.754627 \\
& $(1.48679)$ \\
& $(1.85273)$ \\
\hline \hline R-squared & 0.934702 \\
Adj. R-squared & 0.542912 \\
Sum sq. resides & 0.002499 \\
S.E. equation & 0.049995 \\
F-statistic & 2.385722 \\
Log likelihood & 20.93295 \\
Akaike AIC & -3.483237 \\
Schwarz SC & -3.413725 \\
Mean dependent & 0.481147 \\
S.D. dependent & 0.073948 \\
\hline \hline \multicolumn{2}{c}{ Estimation } \\
\hline \hline
\end{tabular}

LS 12 FRQDA @ BRDSZ BRDID BRDEX ADCMZ EADTQ

VAR Model:
FRQDA $=\mathrm{C}(1,1) * \mathrm{FRQDA}(-1)+\mathrm{C}(1,2) * \mathrm{FRQDA}(-2)+\mathrm{C}(1,3) * \mathrm{BRDSZ}+\mathrm{C}(1,4) * \mathrm{BRDID}+\mathrm{C}(1,5) * \mathrm{BRDEX}+$ $\mathrm{C}(1,6) * \mathrm{ADCMZ}+\mathrm{C}(1,7) * \mathrm{EADTQ}$

VAR Model - Substituted Coefficients: 
FRQDA $=0.5579454706 *$ FRQDA $(-1)+0.3522409771 *$ FRQDA(-2) + 16.01850106*BRDSZ - 0.993786982*BRDID $+0.05531129474 * \mathrm{BRDEX}-20.01456483 * \mathrm{ADCMZ}+2.754627006 * \mathrm{EADTQ}$

Source: E-views result extract, 2016.

Table 2 above shows the relative and global statistics of the model estimate. Issue of Corporate Governance in today's business world became an issue of concern following the weight of monetary crises and financial scandals that were recorded in the economy of most countries in Asia, America, United Kingdom and even in Africa. Notable among these are the cases of Enron (in Enron Vs. Anderson) in the UK, WorldCom in the United State, Kimia Farma and Bank Lippo in Indonesia, and the case of Abacus Merchant Bank in Nigeria (Dabor and Adeyemi, 2009; Dabor and Tijjani, 2011. Relative statistics result shows that board structure (size-BRDSZ), board experience (experienceBRDEX) and the quality of external audit (EADTQ) have positive impact on the financial reporting quality measured by the discretionary accruals of firm (FRQDA) by 16.01, 0.05 and 2.75 . However, independent directors on the board of firm (independence-BRDID) and audit quality (audit committee size (ADCMZ) negatively affect financial reporting quality measured by the discretionary accruals of firm (FRQDA) as much as 0.99 and 20.01. This is a result of the fact that sensitivity of modern businesses where ownership (i.e. shareholders and other stakeholders) is separated from management (i.e. the board of directors) and the series of financial scandals and monetary crises already recorded in the past have emphasized the need for ensuring quality in financial reporting (Karamaou and Vafeas, 2005; Beekes and Brown, 2006; Brown and Caylor, 2006; Firth, Fung and Rui, 2007, Petra, 2007; Nesrine and Abdelwahed, 2011). Among the exogenous variables, independent directors on the board of firm (independence-BRDID) and quality of external audit (EADTQ) are statistically significant with FRQDA. This implies that the driving forces of FRQDA are BRDID and EADTQ. Exogenous variables in the model indicate that, the parameters have very high level of correlation between the FRQDA by 0.9347 . This suggests that the correlation among corporate governance indicators of board structure (size-BRDSZ and independence-BRDID), audit quality (audit committee size (ADCMZ), the quality of external audit (EADTQ) as measured by the presence of an auditor among the big-4), board experience (i.e. experience-BRDEX) and financial reporting quality is $93.47 \%$. The independent variables can explain the variation in the FRQDA by $54.29 \%$. There is overall significance among the parameters measuring financial reporting quality as discretionary accruals of firm (FRQDA).

Table 3: Test result of corporate governance models

\begin{tabular}{|c|c|c|c|}
\hline $\begin{array}{l}\text { Pairwise Granger Causality Tests } \\
\text { Date: 02/18/16 Time: 22:00 } \\
\text { Sample: } 20062015 \\
\text { Lags: } 2\end{array}$ & & & \\
\hline Null Hypothesis: & Obs & F-Statistic & Probability \\
\hline BRDSZ does not Granger Cause FRQDA & 8 & 0.39041 & 0.70681 \\
\hline FRQDA does not Granger Cause BRDSZ & & 22.1538 & 0.01597 \\
\hline BRDID does not Granger Cause FRQDA & 8 & 4.06461 & 0.13995 \\
\hline FRQDA does not Granger Cause BRDID & & 13.1674 & 0.03270 \\
\hline BRDEX does not Granger Cause FRQDA & 8 & 1.35617 & 0.38059 \\
\hline FRQDA does not Granger Cause BRDEX & & 1.03383 & 0.45548 \\
\hline ADCMZ does not Granger Cause FRQDA & 8 & 0.46649 & 0.66619 \\
\hline FRQDA does not Granger Cause ADCMZ & & 26.4637 & 0.01242 \\
\hline EADTQ does not Granger Cause FRQDA & 8 & 0.18718 & 0.83829 \\
\hline FRQDA does not Granger Cause EADTQ & & 0.42388 & 0.68845 \\
\hline
\end{tabular}

Source: E-views result extract, 2016.

From the table 3 of granger causality test result of corporate governance models for quality financial reporting reveals that corporate governance indicators of board structure (size-BRDSZ and independence-BRDID) do not granger cause financial reporting quality as discretionary accruals of firm (FRQDA). Financial reporting quality as discretionary accruals of firm (FRQDA) granger causes corporate governance indicators. This reveals that there is short run 
relationship among Audit quality (audit committee size (ADCMZ), and the quality of external audit (EADTQ) as measured by the presence of an auditor among the big-4) and board experience (i.e. experience-BRDEX) have not granger cause FRQDA. However, FRQDA grange cause Audit quality (audit committee size (ADCMZ) but does not granger causes the quality of external audit (EADTQ) as measured by the presence of an auditor among the big-4) and board experience (i.e. experience-BRDEX). In the short run, corporate governance indicators and Audit quality influence the quality of financial reporting among the firms in Nigeria. The quality of information presented in the financial report through emphases on an effective corporate governance system will determine the shareholders' confidence on the financial reports. However, according to Dabor and Adeyemi (2009), this may not hold due to weak corporate governance structures, codes and institutions which tend to diminish the shareholders' confidence. Hence, their confidence level is low, it may result to "insider trading", caused by shareholders who are not satisfied with the directors' financial report and are willing to pay in order to get more information on the internal operations of the directors. Since information has become a commodity, this may force other unsatisfied shareholders who may not be willing to pay or cannot afford the extra cost to switch investments.

Table 5: Mean Performance Analysis Five Selected Banks

\begin{tabular}{cccccc}
\hline Companies & BRDSZ & BRDID & BRDEX & ADCMZ & EADTQ \\
\hline A.G. Leventis Nigeria Plc. & 9 & 0.207 & 0.517 & 6 & 2 \\
Cadbury Nig. Plc & 11.2 & 0.232 & 0.697 & 6.5 & 2 \\
Forte Oil Plc. & 9.6 & 0.3 & 0.502 & 5.6 & 2 \\
Nigerian Brewery Plc. & 9 & 0.207 & 0.517 & 6 & 2 \\
Guarantee Trust Bank Plc. & 12.6 & 0.22 & 0.419 & 7.5 & 1.5 \\
\hline
\end{tabular}

BRDSZ-Board Size, BRDID-Board Independence, BRDEX-Board Experience, ACDMZ-Audit Committee Size, EADTQ-External Audit Quality, FRQDA-Financial Reporting Quality

Mean performance analysis shows that corporate governance indicators of board structure (independence-BRDID) are higher in Guarantee Trust Bank Plc follows by Cadbury Nig. Plc In terms of corporate governance indicators of board structure (size-BRDSZ), the mean of performance is noticeable in Fortes Oil, Guarantee Trust Bank Plc and Cadbury Nig. Plc. Cadbury Nig. Plc, A.G. Leventis and Nigerian Brewery Plc have relatively equal performance in board experience (i.e. experience-BRDEX). Guarantee Trust Bank Plc and Cadbury Nig. Plc perform significantly higher in audit quality (audit committee size (ADCMZ). On the average, similar trend of performance are observed among the companies with regards to the quality of external audit (EADTQ) as measured by the presence of an auditor among the big-4). On the whole, corporate governance and quality of financial reporting, GTB Plc as a financial company in Nigeria record huge achieve as compare to other companies understudy. Although prior studies such as Wright, (1996); Beasely, (1996); Beasely, (2001); Xie, Davidson and Dadalt, (2001); Krishnamoorthy, Wright and Cohen, (2002); Sanda, Mikailu and Tukur, (2004); Abdulrahman and Hanifa, (2005); Musa, (2006); Ofoegu and Okoye (2006), Hamid (2008); Hassan, (2008); Dabor and Adeyemi, (2009); Dabor and Tijjani(2011); Abbas, (2011); Alzoubi, 2012; and Hassan, (2013) have created associations between corporate governance and financial reporting quality both in developed and developing countries.

\section{Conclusion}

Generally, this paper has been able to establish empirical links between corporate governance system of Nigerian firms and shareholder' confidence on the quality of financial reports which is in line with the studies of Abbas, (2011); Alzoubi, 2012; and Hassan, (2013) that corporate governance system of firms serves as a way of getting the directors to pursue the interest of the shareholder as it affect the financial reporting quality of such firms thereby winning the shareholders' confidence based on the quality of information in the reports. The study suggests that in the short run, corporate governance indicators and Audit quality influence the quality of financial reporting among the firms in Nigeria. Guarantee Trust Bank Plc among the five selected companies of study in Nigeria has better performance of financial reporting based on board structure (size-BRDSZ) and audit committee size (ADCMZ). 


\section{Recommendations}

Based the findings, the study recommends that; corporate governance indicators should be taking seriously by any firm in Nigeria as it helps in the quality of financial reporting. Also since, the audit committee size (ADCMZ). And independent director of board size (BRDID) drive the financial reporting quality, effort should be made at firm having vibrant board size structure and the accurate audit commit size. There should be greater focus on corporate governance measures so as to bring about global standard financial reporting in the Nigerian emerging market for investment opportunities.

\section{Reference}

- $\quad$ Abass, A. (2011), "Corporate Governance and Accounting Conservatism in the Nigerian Foods and Beverages Industry", Bayero University, Kano.

- $\quad$ Abdul Rahman, R., \& Haniffa, R. M. (2005), "The Effect of Role Duality on Corporate Performance in Malaysia. Corporate Ownership and Control", Vol. 2 No. 2 pp40-47.

- Agrawal, A. \& Chadha, S. (2005), "Corporate Governance and Accounting Scandals", Journal of Law and Economics, 48, (2), 371-406. CrossRef

- Ahmed, K., Hossain, M. \& Adams, M. (2006), "The Effects of Board Composition and Board Size on the Informativeness of Annual Accounting Earnings". Corporate Governance: An International Review, 14, (5), 418-431. CrossRef

- $\quad$ Alzoubi, E.S.S. (2012), "Board Characteristics and Financial Reporting Quality Among Jordanian Listed Companies: Proposing Conceptual Framework", Asian Journal of Finance \& Accounting Vol. 4, NoISSN 1946-052X

- $\quad$ Arabsalehi, M. and Ziaee, M. (2010), "The relationship between corporate governance mechanism and earnings quality of listed companies in Tehran Stock Exchange", Financial Accounting, Vol. 2 No 5. pp. 3956.

- $\quad$ Beasley, M. and Salterio, S. (2001), "The Relationship between Board Characteristics and Voluntary Improvement in the Capacity of Audit Committee to Monitor". Contemporary Accounting Research Vol.18, pp539-570 CrossRef

- Beekes, W. \& Brown, P. (2006), "Better-Governed Australian Firms Make More Informative Disclosures". Journal of Business Finance and Accounting, 33, (3), 422-450. CrossRef

- Bradbury, M., Mak, Y. \& Tan, S. (2006), "Board characteristics, audit committee characteristics and abnormal accruals". Pacific Accounting Review, 18, 47-68. CrossRef

- $\quad$ Brown, J., Falaschetti, D. \& Orlando, M. (2010), "Auditor Independence and Earnings Quality: Evidence for Market Discipline vs. Sarbanes-Oxley Proscriptions". American Law and Economics Review, 12, (1), 39-68. CrossRef

- $\quad$ Brown, L. \& Caylor, M. (2006), "Corporate Governance and Firm Valuation", Journal of Accounting and PublicPolicy, 25, (4), 409-434. CrossRef

- Bushman, R., Chen, Q., Engel, E. \& Smith, A. (2004), "Financial Accounting Information, Organizational Complexity and Corporate Governance Systems", Journal of Accounting and Economics, 37, (2), 167-201. CrossRef

- $\quad$ Byard, D., Li, Y. \& Weintrop, J. (2006), "Corporate Governance and the Quality of Financial Analyst's Information", Journal of Accounting and Public Policy, 25, 609-625. CrossRef

- Cornett, M.M McNutt, J.J Tehranian, H. (2009), "Corporate governance and earnings management at large U.S. bank holding companies", Journal of Corporate Finance 15, 412-430. CrossRef

- Dabor, E. L and Tijjani, B. (2011), "Corporate Governance and Corporate Disclosure; in Dandago and Tijjani (ed) Corporate Governance and Social Responsibility", Department of Accounting Bayero University Kano.

- Dabor, E. L. and Adeyemi, S. B. (2009), "Corporate Governance and the Credibility of Financial Statement". Journal of Business Systems, Governance and Ethics. Vol. 4 No.1.

- Dechow, Ge, \& Schrand (2010), "Understanding earnings quality: A review of the proxies, their determinants and their consequences", Journal of Accounting and Economics. 50(3).344-401.

- Dechow, P., R. Sloan, \& A. Sweeney. (1995), "Detecting earnings management", The Accounting Review. 70. 193-225

- Dechow, P.M. \& Dichev, I.D. (2002), "The quality of accruals and earnings: The role of accrual estimation errors", The Accounting Review. 77. 35-59. CrossRef

- Dimitropoulos, P. \& Asteriou, D. (2010), "The Effect of Board Composition on the Informativeness and Quality of Annual Earnings: Empirical Evidence from Greece", Research in International Business and Finance, 24, 190-205. CrossRef 
- $\quad$ Erena, O.T. and Tehulu, T. A. (2012), "The Impact of Corporate Governance Mechanisms on Earnings Management: Evidence from Banks in Ethiopia", International Journal of Research in Commerce, Economics and Management. Vol. 2, No, 8 ISSN 2231-4245.

- $\quad$ Farber, D. (2005), "Restoring Trust after Fraud; Does Corporate Governance Matter?", The Accounting Review, Vol. 80, pp539-561 CrossRef

- $\quad$ Firth, M., Fung, P. \& Rui, O. (2007), "Ownership, two-tier Board Structure, and the Informativeness of Earnings: Evidence from China. Journal of Accounting and Public Policy, 26, (4), 463-496. CrossRef

- Greco, G. (2012), "Ownership Structure, Corporate Governance and Earnings Management in European Oil Industry". http//ssrn.com/abstract=2015590 $\underline{\text { CrossRef }}$

- Hamid, K.T. (2008), "An Assessment of the Relationship between corporate Governance and Internal Control System in the Nigerian Banking Industry". A Ph.D Accounting Thesis Submitted to the School of Post Graduate Studies, Bayero University, Kano.

- Hassan, S. U. (2013), "Financial Reporting Quality, Does Monitoring Characteristics Matter? An Empirical Analysis of Nigerian Manufacturing Sector", A Paper presented at the International Conference in Accounting and Finance, Dubai, UAE. (2012).

- Jensen, M.C., (1993), "The Modern Industrial Revolution Exit, and the Failure of Internal Control System", Journal of Finance.48.831-880.

- Jones, J. (1991), "Earnings management during import relief investigation", Journal of Accounting Research .29.193-228.

- Jouini, F., (2013), "Corporate Governance System and Quality of Information: Mediterranean" Journal of Social Sciences, Vol 4, No. 2, (P) 129-142.

- Karamanou, I. \& Vafeas, N. (2005), "The Association between Corporate Boards, Audit Committees, andManagement Earnings Forecasts: An Empirical Analysis", Journal of Accounting Research, 43, (3), 453 486. CrossRef

- Kent, P. and Stewart, J. (2008), Corporate Governance and Disclosures on the Transition to International Financial Reporting standards. School of Business. http:/ / epublications.bond.au/business_pubs/130. Accessed on 13/09/2012. CrossRef

- Klein, A. (2002), "Audit Committee, Board of Director Characteristics and Earnings Management". Journal of Accounting and Economics, 33, 375-400. CrossRef

- Krishnamoorthy, G., Wright, A and Cohen, J. (2002), "Audit Committee Effectiveness and Financial Reporting Quality: Implication for Auditor Independence". Australian Accounting Review, Vol 3. No 13.

- $\quad$ Leung Q W Y, Morris R D \& Gray S J, (2005), "Corporate transparency in China: Factors influencing financial disclosure levels". Working Paper, School of Accounting, University of New South Wales.

- Mehrani, K \&Safarzade. M. (2011). "Explaining the relationship between corporate governance and earnings quality with local approach", Accounting science, Vol. 2 No. 7. pp. 69-98 PMCid:PMC3167199

- Musa, F.I. (2006), "The Impact of Corporate Governance on the Performance and Value of Banks in Nigeria: An Agency Approach". Nigerian Journal of Accounting Research. No 4 June, pp 1-15

- Nesrine, K., \& Abdelwahed, O.(2011). "Corporate Governance and Financial Reporting Quality: The Case of Tunisian Firm", International Business Research 4, 1, pp. 158-166.

- Ofoegbu, G. and Okoye, E. (2006), "The Relevance of Accounting and Auditing Standards in Corporate Financial Reporting in Nigeria; Emphasis on Compliance". The Nigerian Accountant, Vol.39 No. 4 pp 45-53.

- $\quad$ Peasnell, K., Pope, P. \& Young, S. (2000), "Accrual Management to Meet Earnings Targets: UK Evidence Pre- and Post-Cadbury". British Accounting Review, 32, 415-445. CrossRef

- Petra, S. (2007), "The Effects of Corporate Governance on the Informativeness of Earnings. Economics of Governance", 8, 129-152. CrossRef

- Prawit, Douglas F. Smith, Jason L. Wood, David A. (2009), "Internal Audit Quality and Earnings Management", The Accounting Review. Vol. 84. Nomor 4. Pp. 1255-1280.

- $\quad$ Rezaee .Z. and Riley .R. (2010), Financial Statement Fraud; Prevention and Detection" Second Edition. John Wiley \& Son Inc.

- $\quad$ Rezaee, Z. (2008), High Quality Financial Reporting (The Six-Legged Stool). Strategic Finance. PMCid:PMC2390549

- $\quad$ Sanda, A U, Mukaila, A S and Garba, T (2005): "Corporate Governance Mechanisms and Firm Financial Performance in Nigeria", AERC Research Paper, No. 149

- VanBeest F., Braam G., \& Boelens S. (2009), "Quality of Financial Reporting: measuring qualitative characteristics", Nijmegen Center for Economics (NiCE) Working Paper 09-108.

- Wright, D.W. (1996), 'Evidence on the Relationship between Corporate Governance Characteristics and the Quality of Financial reporting". Working Paper University of Michigan. 
- Xie, B., Davidson, W. N and DaDalt, P. J. (2001), "Earning Management and Corporate Governance: The Role of the Board and the Audit Committee", Working Paper. Southern Illinois University.

- Zain-aldini Maymand, L. (2011), "The impact of corporate governance on the relationship between capital structure and firm value". MA Thesis; Yazd Islamic Azad University.

\section{Appendix}

Table 6

\begin{tabular}{|c|c|c|c|c|c|c|c|}
\hline \multirow[t]{8}{*}{ A.G. Leventis Nigeria Plc. } & Statistic & BRDSZ & BRDID & BRDEX & ADCMZ & EADTQ & FRQDA \\
\hline & Total & 90 & 2.07 & 5.17 & 60 & 20 & -2.57 \\
\hline & Sample Size & 10 & 10 & 10 & 10 & 10 & 10.00 \\
\hline & Mean & 9 & 0.207 & 0.517 & 6 & 2 & -0.26 \\
\hline & Variance & - & 0.00 & 0.01 & - & - & 0.02 \\
\hline & STD & - & 0.02 & 0.10 & - & - & 0.12 \\
\hline & C.V & - & 4517.54 & 1028.93 & - & - & 812.90 \\
\hline & Statistic & BRDSZ & BRDID & BRDEX & ADCMZ & EADTQ & FRQDA \\
\hline \multirow{7}{*}{ Cadbury Nig. Plc } & Total & 112 & 2.32 & 6.97 & 65 & 20 & -3.54 \\
\hline & Sample Size & 10 & 10 & 10 & 10 & 10 & 10 \\
\hline & Mean & 11.2 & 0.232 & 0.697 & 6.5 & 2 & -0.35 \\
\hline & Variance & 1.07 & 0.00 & 0.02 & 0.28 & - & 0.02 \\
\hline & STD & 1.03 & 0.02 & 0.13 & 0.53 & - & 0.14 \\
\hline & C.V & 96.82 & 5175.49 & 773.54 & 189.74 & - & 737.39 \\
\hline & Statistic & BRDSZ & BRDID & BRDEX & ADCMZ & EADTQ & FRQDA \\
\hline \multirow{7}{*}{ Forte Oil Plc. } & Total & 96 & 3 & 5.02 & 56 & 20 & -2.87 \\
\hline & Sample Size & 10 & 10 & 10 & 10 & 10 & 10 \\
\hline & Mean & 9.6 & 0.3 & 0.502 & 5.6 & 2 & -0.29 \\
\hline & Variance & 0.27 & 0.01 & 0.03 & 0.27 & - & 0.01 \\
\hline & STD & 0.52 & 0.11 & 0.16 & 0.52 & - & 0.11 \\
\hline & C.V & 193.65 & 901.26 & 620.23 & 193.65 & - & 915.57 \\
\hline & Statistic & BRDSZ & BRDID & BRDEX & ADCMZ & EADTQ & FRQDA \\
\hline \multirow{7}{*}{ Nigerian Brewery Plc. } & Total & 90 & 2.07 & 5.17 & 60 & 20 & -3.04 \\
\hline & Sample Size & 10 & 10 & 10 & 10 & 10 & 10 \\
\hline & Mean & 9 & 0.207 & 0.517 & 6 & 2 & -0.30 \\
\hline & Variance & - & 0.00 & 0.01 & - & - & 0.01 \\
\hline & STD & - & 0.02 & 0.10 & - & - & 0.08 \\
\hline & C.V & - & 4517.54 & 1028.93 & - & - & 1316.41 \\
\hline & Statistic & BRDSZ & BRDID & BRDEX & ADCMZ & EADTQ & FRQDA \\
\hline \multirow{6}{*}{ Guarantee Trust Bank Plc. } & Total & 126 & 2.2 & 4.19 & 75 & 15 & -3.44 \\
\hline & Sample Size & 10 & 10 & 10 & 10 & 10 & 10 \\
\hline & Mean & 12.6 & 0.22 & 0.419 & 7.5 & 1.5 & -0.34 \\
\hline & Variance & 6.27 & 0.00 & 0.06 & 1.39 & 0.28 & 0.02 \\
\hline & STD & 2.50 & 0.06 & 0.24 & 1.18 & 0.53 & 0.13 \\
\hline & C.V & 39.95 & 1749.64 & 424.48 & 84.85 & 189.74 & 744.48 \\
\hline
\end{tabular}

BRDSZ-Board Size, BRDID-Board Independence, BRDEX-Board Experience, ACDMZ-Audit Committee Size, EADTQ-External Audit Quality, FRQDA-Financial Reporting Quality 